\title{
Ełona Curkan-Dróżka
}

$$
|\mathbf{C}| \mathbf{O}|\mathbf{P}| \mathbf{E} \mid
$$

(iD) https://orcid.org/0000-0002-5256-433X

Uniwersytet Łódzki

Wydziat Filologiczny

Instytut Rusycystyki

Zakład Przekładu i Dydaktyki

90-236 Łódź

ul. Pomorska 171/173

elona.curkan@uni.lodz.pl

\section{III Международная научно-практическая конференция «Русский язык в межкультурном общении - теория и практика»}

\author{
III International Scientific and Practical Conference \\ "Russian in Intercultural Communication - Theory and Practice"
}

\section{Резюме}

В настоящем обзоре речь идёт о Международной научно-практической конференции, организованной Институтом русистики, Кафедрой перевода и дидактики в 2019 году. Обсуждаются вопросы, связанные с темами докладов, а также практическими результатами конференции.

\section{Summary}

This review looks back at the International Scientific and Practical Conference organized by the Department of Translation and Didactics, Institute of Russian Studies, in 2019. The authors discuss the themes of submitted papers as well as practical outcomes of the conference.

С 19 по 21 сентября 2019 года в Лодзинском университете на филологическом факультете состоялась III Международная научно-практическая конференция «Русский язык в межкультурном общении - теория и практика», организованная Институтом русистики, Кафедрой перевода и дидактики. Конференция была посвящена широкому спектру вопросов из областей глоттодидактики и перевода. 
В конференции приняли участие опытные и начинающие ученые, преподаватели и студенты из следующих государств: Польша, Россия, Латвия и Болгария. Среди участников были авторы учебников для изучения русского языка как иностранного на разных уровнях - на базовом этапе обучения в начальных школах, для студентов, начинающих изучение русского языка с целью дальнейшего поступления в высшие учебные заведения России, а также для польских студентов, обучающихся русскому языку в вузах и языковых школах на продвинутом уровне. Интереснейший обмен мнениями и новыми идеями прошёл в секции, посвященной лингвокульторологии.

Своим опытом делились также ученые, занимающиеся исследованиями и практикой в области перевода. В представленных докладах были предложены новаторские решения в сфере литературного перевода и новые подходы к обучению переводческой деятельности по разным направлениям: аудиовизуальный перевод, перевод художественных текстов, использование комикса в дидактике перевода. Участники конференции могли включиться в работу следующих секций:

- Методика преподавания РКИ,

- Лингвокультурология,

- Перевод художественных текстов. Обучение переводу,

- Новые типы пользователей РКИ. Русский язык в специальных целях.

Необходимо также упомянуть о практическом аспекте состоявшейся конференции, а именно о мастер-классах, для которых был отведен отдельный день, с целью предоставить возможность участия всем желающим. Данные встречи были посвящены практическим советам и установкам по созданию авторских учебников для разных возрастных категорий. Интересным акцентом была презентация разработанной программы для обучения самых маленьких учеников: «Русский язык для детского сада (методика преподавания для славяноязычных детей)».

Дискуссии переходили из аудиторий в кулуары, продолжаясь после окончания работы в секциях. Увлечение участников свидетельствует о необходимости проведения научно-практических конференций. Главной целью таких встреч является создание общего пространства для преподавателей, обучающих русскому языку учащихся разных возрастных категорий, с разным уровнем владения языком, с помощью разных каналов общения (непосредственный контакт - аудиторные и внеаудиторные занятия, платформа MOODLE, форумы) и тем не менее преследующих общую цель - учить целостно, интересно, увлекая своих слушателей и открывая перед ними огромное количество возможностей знакомства с русским языком и культурой. 